\title{
Blockchain is Top Skill For 2020
}

\author{
Datu Mohammed ${ }^{1}$, Nur Aisha ${ }^{2}$, Arzo Himki ${ }^{3}$, Arusyi Dithi ${ }^{4}$, Agung Yudo Ardianto ${ }^{5}$ \\ (Universitas Malaysia Terengganu, Universitas Sultan Zainal Abidin, Panjab University, \\ University of Pune, Raharja University) \\ e-mail: datumohammed@yahoo.com, nuraisha890@yahoo.com, arzohimki@yahoo.com, \\ arusyidithi@yahoo.com, agung.yudo@raharja.info
}

To cite this document:

Mohammed, D., Aisha, N., Himki, A., Dithi, A., \& Ardianto, A. Y. (2020). Blockchain Is Top Skill For 2020. Aptisi Transactions on Technopreneurship (ATT), 2(2). https://doi.org/10.34306/att.v2i2.101

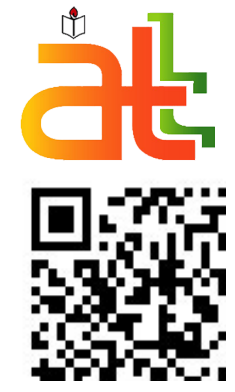

Autor Notifications

23 July 2020

Final Revised

24 August 2020

Published

30 September 2020

\begin{abstract}
This research aims to learn why Blockchain Technology can be the most demanding hard skills in companies in 2020 as quoted from Linkedln and the positive impact that Blockchain Technology has on a company. If we see, at this time usually requires at least a third party to make a transaction, and a company usually only stores data / information on a centralized server which makes the data easy to hack. From this case, Blockchain technology can be used as a way out for a company to make data / information not easy to be hacked. Because, Blockchain uses a distributed server system that is validated, which makes Blockchain safer from evil parties who want to hack information, and Blockchain has other advantages such as more cost-effective, better transparency and traceability. Therefore Blockchain Technology is a particular attraction for a company and is the hard skill most demanded by the company in 2020 (Hou, 2017). Other than that, the benefit of this research is to disseminate it to companies that do not know blockchain and can immediately find out and use this profitable technology.
\end{abstract}

Keywords: Skill, Blockchain,Technology, Company

\section{Introduction}

Some companies mention that Blockchain Technology is a transformational technology [1]. This Blockchain technology has emerged from the world of cryptocurrency which was once not so visible but is now a business solution in solving a problem [2]. Basically Blockchain is a very large shared digital book and Blockchain Technology has the advantages of which are decentralized, cost effective and time to transparently track shipments and transactions of all types [3] (Hariguna et al., 2019).

Blockchain has become a line of business for anyone in the corporate world and Blockchain has begun to be used in various industries ranging from shipping to health care, from agriculture and food safety to entertainment and games [4] (Santoso et al., 2019). In addition, there have been many large companies that use Blockchain Technology including: from supply chain companies namely Unilever, De Beers, Ford, from insurance companies: AIA Group, MetLife, Aig, Aegon and many more companies that use Blockchain Technology this [5]. 
The problem is that there are still many who don't know its advantages. Because all around we are familiar with using third parties as transactions and it has become our habit to use third parties to make transactions.

\section{Research Method}

Blockchain is a digital record that can be used as a transaction record that is disseminated on many computers. If interpreted one by one Block is an individual record, and the chain is (a chain) that functions as a link in 1 list (Zhang et al., 2020). Blockchain is used as a recording of transactions made with cryptocurrency such as Bitcoin and other applications (Sunarya et al., 2019).

\subsection{Literature Review}

In this section, we will discuss in more detail what Blockchain is and what are the positive impacts that Blockchain Technology has on companies today.

Blockchain technology has its own interests for many companies today, where certainly a company needs employees who have the hard skills needed as the ability of employees to perform certain tasks, and in 2020 Blockchain has been ranked first as the most hard capabilities demanded by companies like those who quoted from Linkedln [10]. This research is very different from other studies that only study the understanding of Blockchain Technology, but this research will discuss more clearly why Blockchain Technology can become the number 1 hard capability most demanded by companies in 2020 [11]. Blockchain technology is of particular interest because of its advantages which are a business solution for a company, including :

1. Better transparency: Blockchain technology is (cannot be changed), safe and transparent. Making transactions on Blockchain Technology through public address can be seen by a user through explorer and public address, at that time we can see how many accounts someone has and can see where he will transfer the money [12] (Tsiulin et al., 2020).

2. Security: To make a transaction, it must first be verified by the miner before it is recorded on multiple nodes, once verified, it will be encrypted and connected to the previous transaction through a hash. If previously only using a centralized database such as SQL, it would be easier for a hacker / who has malicious intent to change the data (Garcia-Teruel, 2020). A hacker could have hacked the data and changed it, because it is easier to hack, because the data is only stored on a centralized server, and there could be someone who intends to do it and by bribing a database administrator to change the data [13].

3. Efficiency: If we use a traditional system that still uses paper, it will take a lot of time and increase human error. By tidying up the flow and automating this process with Blockchain technology, transactions will be faster and more efficient to complete [14] (Ramkumar, 2018). 
4. Cost Savings: All businesses / companies certainly want this, which is cost savings. With the Blockchain Technology, we no longer need a third party and just trust the data in the Blockchain and don't need to see many things to complete a transaction, because every individual has access permission for the same (single) data (Zheng et al., 2017).

5. Audit \& trace tracks: If data is entered into the Blockchain there will be an audit trail that allows us to find out where an asset is from and every checkpoint it passes(Qi et al., 2020).

\subsection{Research Question}

Based on the literature review above, it can be concluded in 3 (three) final research questions as follows:

(1) Does a company have to look for new people who have the hard capabilities of Blockchain Technology?

(2) Can Blockchain be the right solution to replace a digital recording system in an existing company?

(3) Has Blockchain Technology been used in companies in Indonesia?

\section{Findings}

In this section will be divided into 2 parts: Problem and Research Implementation which will be the result of this research.

\subsection{Problem}

(1) Does a company have to look for new people who have the hard capabilities of Blockchain Technology?

The purpose of this research question is to find solutions and identify existing problems in a company that is, Does a company have to look for new employees who have the hard ability of Blockchain Technology? .

A company can choose 2 choices to determine the solution namely, find new employees or old employees trained to learn Blockchain Technology(Pan et al., 2020). Both of these options have their advantages and disadvantages, which are:

If the company chooses to look for new employees (Strengths and Weaknesses):

$(+)$ No need to train employees to learn about Blockchain Technology.

(+) New employees can directly implement Blockchain Technology to a company.

(-) New employees must adapt again to their new environment and work.

If the company chooses to train old employees (Strengths and Weaknesses):

$(+)$ Old employees can adapt. Both the environment and work.

(-) It takes a long time to train old employees to learn about Blockchain Technology.

(-) Not necessarily old employees can implement Blockchain Technology to a company, even though they have studied the technology.

(-) Requires additional costs for a company to train old employees. Which one has to pay someone else to train old employees. 
Based on consideration through various aspects, we can conclude that to find new employees who already have hard skills Blockchain technology is the best solution. Because a company will no longer consider the deficiencies in option 2 that will later make a company have a new problem that will have a fatal impact (Treiblmaier, 2018) .

(2) Can Blockchain be the right solution to replace a digital recording system in an existing company?

In the second part will discuss whether Blockchain Technology is the right solution to replace the digital Recording System in an existing company ?, We conclude by considering the following aspects:

1. Security

2. Keep away human errors

3. Cost effective

Previously, a company used a Digital Recording System that uses a centralized server, which has the following disadvantages:

1. Easier to hack, because hackers will only hack 1 server and when the bad party has hacked. Then the data / information will be leaked and could have been used by an evil party that could harm a company(Sikorski et al., 2017).

If a company uses recording in the traditional way such as writing using paper, it has the following disadvantages:

1. Human Error: Because humans have limitations, where human error can occur such as missing bookkeeping, incorrect writing, and so forth.

2. Inefficient: Not efficient, because the amount of data / information in a company can be very much which makes spending time if you want to find data before using this method (Harris \& Wonglimpiyarat, 2019).

Blockchain technology can be a solution for all the problems that exist in a digital record now(Crosby et al., 2016). In terms of security, Blockchain Technology uses a decentralized system which the server system is distributed on many servers / data has been encrypted to all members of the blockchain(Joshi et al., 2018). From the Blockchain efficiency level is better, because only by tidying up the flow and automating this process transactions will be faster to complete. And from the cost savings of Blockchain not needing to use 3rd parties and overhead costs to exchange assets, Blockchain can be a solution to reduce transaction costs (Oh et al., 2017).

\section{(3) Has Blockchain Technology been used in companies in Indonesia?}

We already know that Blockchain technology is a digital recording technology that is very powerful with its strengths. Not only companies abroad have used Blockchain Technology, in Indonesia too many companies have started using Blockchain Technology such as Ledger Now, IBM, Blockchain Zoo and others (George et al., 2019).

\subsection{Research Implementation}


Blockchain can be the answer to all the disadvantages of transactions at this time. Its strengths and the way blockchain technology overcomes the current shortcomings are the most sought after by companies at the moment and make the most desirable capabilities in 2020 as quoted by Linkedln (J. Sun, 2016)

\section{Conclusion}

Blockchain technology has been used in many companies today, Transparency, decentralization, and safety are the basis of this technology. For example, the company that uses Blockchain Technology is Unilever. Unilever uses Blockchain Technology to increase transparency in the tea supply chain(Mettler, 2016).

The purpose of starting this Unilever project is to provide quality and premium products for customers and to gain customer loyalty. In addition, the company also wants to reduce the tracking time needed for tea from farmers to stores (Yoo, 2017). This pilot project is run by Unilever for one year. Blockchain technology This is used to track the tea supply chain and this project involves partnerships with banks and technology startups to track tea farmers in Malawi. It is estimated to reach around 10,000 farmers(Treleaven et al., 2017). The main objective of the project is to ensure transparency in the system so that consumers and companies know about the origin of tea(Miraz \& Ali, 2018).

\section{References}

[1] M. Zarlis, E. P. Harahap, and L. N. Husna, "Test Appraisal System Application Based on YII Framework as Media Input Student Value Final Project and Thesis Session at Higher Education," Aptisi Transactions On Technopreneurship (ATT), vol. 1, no. 1, pp. 73-81, 2019.

[2] S. Tsiulin, K. H. Reinau, O. P. Hilmola, N. Goryaev, and A. Karam, "Blockchain-based applications in shipping and port management: a literature review towards defining key conceptual frameworks," Review of International Business and Strategy, vol. 30, no. 2, pp. 201-224, 2020, doi: 10.1108/RIBS-04-2019-0051.

[3] R. M. Garcia-Teruel, "Legal challenges and opportunities of blockchain technology in the real estate sector," Journal of Property, Planning and Environmental Law, 2020, doi: 10.1108/JPPEL-07-2019-0039.

[4] H. Treiblmaier, "The impact of the blockchain on the supply chain: a theory-based research framework and a call for action," Supply Chain Management, vol. 23, no. 6, pp. 545-559, 2018, doi: 10.1108/SCM-01-2018-0029.

[5] S. Santoso, J. Kauf, and N. C. Aristo, "The Information System of Name Card Sales Based on Digital Marketing to Improve Creativepreneur on College E-Commerce Website," Aptisi Transactions On Technopreneurship (ATT), vol. 1, no. 1, pp. 64-72, 2019.

[6] P. A. Sunarya, D. D. Bernard, and D. M. Damanik, "Viewboard Implementation Based on Javascript Charts as a Media for Submitting Sales Information on a Green E-Commerce Website Light Cafe," Aptisi Transactions On Technopreneurship (ATT), vol. 1, no. 1, pp. 11-19, 2019. 
[7] T. Hariguna, M. Yusup, and A. Priyadi, "The Transaction Optimization Of Color Print Sales Through E-Commerce Website Based On Yii Framework On Higher Education," Aptisi Transactions On Technopreneurship (ATT), vol. 1, no. 1, pp. 1-10, 2019.

[8] I. B. P. Bhiantara, "Teknologi Blockchain Cryptocurrency Di Era Revolusi Digital," Seminar Nasional Pendidikan Teknik Informatika (SENAPATI), vol. 9, no. September, pp. 173-177, 2018, [Online]. Available: http://eproceeding.undiksha.ac.id/index.php/senapati/article/view/1204.

[9] M. Risius and K. Spohrer, "A blockchain research framework," Business \& Information Systems Engineering, vol. 59, no. 6, pp. 385-409, 2017.

[10] Zarlis, M., Harahap, E. P., \& Husna, L. N. (2019). Test Appraisal System Application Based on YII Framework as Media Input Student Value Final Project and Thesis Session at Higher Education. Aptisi Transactions On Technopreneurship (ATT), 1(1), 73-81.

[11] Zheng, Z., Xie, S., Dai, H., Chen, X., \& Wang, H. (2017). An overview of blockchain technology: Architecture, consensus, and future trends. 2017 IEEE International Congress on Big Data (BigData Congress), 557-564.

[12] Pilkington, M. (2016). Blockchain technology: principles and applications. In Research handbook on digital transformations. Edward Elgar Publishing.

[13] Sikorski, J. J., Haughton, J., \& Kraft, M. (2017). Blockchain technology in the chemical industry: Machine-to-machine electricity market. Applied Energy, 195, 234-246.

[14] Sun, J., Yan, J., \& Zhang, K. Z. K. (2016). Blockchain-based sharing services: What blockchain technology can contribute to smart cities. Financial Innovation, 2(1), 1-9.

[15] J. Sun, J. Yan, and K. Z. K. Zhang, "Blockchain-based sharing services: What blockchain technology can contribute to smart cities," Financial Innovation, vol. 2, no. 1, pp. 1-9, 2016. [16] P. Treleaven, R. G. Brown, and D. Yang, "Blockchain technology in finance," Computer, vol. 50, no. 9, pp. 14-17, 2017.

[17] A. P. Joshi, M. Han, and Y. Wang, "A survey on security and privacy issues of blockchain technology," Mathematical foundations of computing, vol. 1, no. 2, p. 121, 2018.

[18] X. Pan, X. Pan, M. Song, B. Ai, and Y. Ming, "Blockchain technology and enterprise operational capabilities: An empirical test," International Journal of Information Management, vol. 52, p. 101946, 2020.

[19] H. Hou, "The application of blockchain technology in E-government in China," in 2017 26th International Conference on Computer Communication and Networks (ICCCN), 2017, pp. $1-4$.

[20] M. H. Miraz and M. Ali, "Applications of blockchain technology beyond cryptocurrency," arXiv preprint arXiv:1801.03528, 2018. 